Kirkham, D. S. (1957). J. gen. Microbiol. 16, 360-373

\title{
Relationships between Gultural Characters and Pathogenicity in Venturia inaequalis and Venturia pirina
}

\author{
BY D. S. KIRKHAM \\ East Malling Research Station, Kent
}

\begin{abstract}
SUMMARY: Series of experiments were carried out both in vitro and in vivo on single conidial isolates of Venturia inaequalis and $V$. pirina. Relationships between colony type and sporulation in vitro were apparent in both species. In addition, isolates of $\boldsymbol{V}$. inaequalis showed relationships between degree of resistance of host source, width of host range and stability of cultural characters and pathogenicity during storage in culture. Isolates of $V$. pirina showed no such relationships, cultural characters being invariably stable while pathogenicity rapidly declined in the storage conditions. Studies of nutritional requirements suggested no deficiencies in the synthetic abilities of either pathogen, but limiting nutritional factors were important. Isolates of both species which differed widely in pathogenicity and other characteristics, reacted similarly to various culture media.
\end{abstract}

The use of Venturia inaequalis (Cke.) Wint. as a test organism for the laboratory evaluation of protective fungicides for use against the apple and pear scab diseases (Montgomery \& Moore, 1938) requires the provision of a routine supply of conidia over long periods. Much difficulty has been experienced in maintaining this supply without frequently obtaining new isolates, and the present study was therefore initiated to investigate sporulation in artificial culture and to determine optimal methods and media. Modifications in the method of fungicide test have been reported (Kirby \& Frick, 1952) and in these, some results of this study have been applied. The scope of the work was later widened to include $\boldsymbol{V}$. pirina Aderh. and studies of possible relationships between cultural characters and pathogenicity in the two species.

\section{METHODS}

Conidia were isolated from fruit or leaf lesions. They were allowed to germinate on $2 \%(\mathrm{w} / \mathrm{v})$ malt-extract agar at $18^{\circ}$ and then isolated singly on small blocks of agar, using a platinum-iridium needle. The blocks were transferred to $2 \%$ malt-extract agar slopes and, after 14 days' incubation at $18^{\circ}$, the cultures were stored at $5^{\circ}$ under sterile B.P. grade paraffin oil to a maximum depth of $1 \mathrm{~cm}$. above the upper edges of the colonies (Buell \& Weston, 1947). Ascospores were collected from moistened overwintered leaves and isolated in the same way.

The morphological differentiation of the isolates was carried out on a standard depth of $2 \%(\mathrm{w} / \mathrm{v})$ malt-extract agar, at $\mathrm{pH} 5 \cdot 6$ before sterilization. The growth of four replicate conidia of each isolate was described and recorded photographically after 6 weeks of incubation at $18^{\circ} ; 2 \%$ malt- 
extract was chosen, as maximum differentiation occurred most rapidly on this medium.

Comparative sporulation of the isolates was determined turbidimetrically after growth on filter-paper cylinders standing in nutrient solutions (Kirkham, 1956). In all tests each treatment was applied in duplicate and the turbidity estimate expressed as the geometric mean of a pair of observations. Geometric means were used so that variability of the means could be expressed in terms of a significant ratio, since it was found that the standard deviation of an observation was proportional to its mean value. Two means differed significantly ( $5 \%$ level of significance) when their ratio exceeded 1.38. Growth on the paper cylinders was recorded at the cultural endpoints, using the following categories : $\mathbf{0}=$ none or traces; $\mathbf{1}=$ thin or inhibited; $\mathbf{2}=$ normal but suboptimal; $3=$ optimal.

The pathogenicity and host ranges of isolates were determined with apple and pear trees, potted in John Innes Compost No. 1, in their second year of growth. Groups of trees were pruned to provide a succession of growing extension shoots during the season. Each scion was initially cut back to $3 \mathrm{ft}$. above the graft union, and a maximum of four buds in the apical zone allowed to produce shoots. The potted trees were plunged in the open and moved batchwise into the greenhouse a month before they were required for inoculation, to avoid the risk of natural infection by Venturia spp.

Shoots between 7 and 12 in. in length were used. The first fully expanded leaf below the shoot tip was labelled on the petiole and designated Lo, to indicate the stage of development at the time of inoculation. Each shoot was enclosed in a polythene sleeve moist chamber $2.5 \mathrm{in}$. diameter and $0.0015 \mathrm{in}$. thick (Stanton, 1951). Areas of unrolled paper cylinders, bearing sporulating mycelium, were placed on glass slides and used as sources of inoculum, to avoid preparation of spore suspensions and possible damage to the conidia. Inoculation was achieved by spraying distilled water from a glass atomizer across the surface of the culture into the moist chamber, which was subsequently closed for $24 \mathrm{hr}$. The sleeve was then opened for $\mathbf{2} \mathrm{hr}$. to allow a gradual adjustment to less humid conditions and finally removed altogether. The degree of infection resulting from each combination of fungal clone and scion variety was recorded 30 and 50 days after inoculation. Symptoms of infection were divided into two main types:

(a) Fleck reaction, which was defined as a chlorotic spot with or without a necrotic centre and bearing no conidia.

(b) Lesion reaction, in which few or many conidia were produced.

During the summer months, adequate shading of the greenhouse was necessary to avoid sun scald, Cox's Orange Pippin being particularly susceptible. The trees were sprayed with water two or three times daily, depending on weather conditions, to control mildew (Podosphaera leucotricha). Infected leaves were removed when possible or the lesions were covered with traces of vaseline. 


\section{RESULTS}

\section{Sporulation and polymorphism in artificial culture}

Fifty-one isolates of Venturia inaequalis were obtained from a wide range of host varieties in order to make a collection which, though small, would be as heterogeneous as possible and provide useful material for comparative studies of cultural characters and pathogenicity. The isolates could not be regarded as physiologically specialized strains and are therefore described as culturally distinct clones. As was expected from the strongly polymorphic nature of the fungus (Palmiter, 1934; Rudloff \& Schmidt, 1934; Schmidt, 1935, 1936a, $b$ ) no two primary lesions yielded the same colony form, but replicate isolations from the same lesion produced colonies identical in appearance with only one exception.

Table 1. Classification of colony characters of Venturia inaequalis and

$$
\text { V. pirina }
$$

\begin{tabular}{|c|c|c|c|}
\hline \multirow[b]{2}{*}{ Colony characters } & \multicolumn{3}{|c|}{ Group } \\
\hline & 1 & 2 & 3 \\
\hline Size (diameter) & Small (<12 mm.) & $\begin{array}{l}\text { Intermediate or } \\
\text { large }\end{array}$ & Large (>20 mm.) \\
\hline $\begin{array}{l}\text { Macroscopic appear- } \\
\text { ance of aerial } \\
\text { mycelium }\end{array}$ & Rough and vertical & Intermediate & $\begin{array}{l}\text { Smooth and } \\
\text { horizontal }\end{array}$ \\
\hline $\begin{array}{l}\text { Predominance of } \\
\text { subaerial or aerial } \\
\text { mycelium }\end{array}$ & $\begin{array}{l}\text { Subaerial (S) or } \\
\text { aerial (A) }\end{array}$ & Subaerial or aerial & Aerial \\
\hline Edge & Poorly defined & Intermediate & Well defined \\
\hline Mycelium at edge & $\begin{array}{l}\text { Hyphae undulating } \\
\text { and profusely } \\
\text { branched }\end{array}$ & Intermediate & $\begin{array}{l}\text { Hyphae straight and } \\
\text { unbranched }\end{array}$ \\
\hline Sporulation at edge & High & Variable & Low \\
\hline Colony type & $1 S$ or $1 \mathrm{~A}$ & $2 \mathrm{~S}$ or $2 \mathrm{~A}$ & $\mathbf{3 A}$ \\
\hline
\end{tabular}

An attempt was made to simplify the description of, and to classify, the many morphological differences between the clones. Colonies were initially divided into three groups depending on the characters listed in Table 1. Predominance of subaerial or aerial mycelium on a standard agar depth was found to be variable within groups 1 and 2 , so a further separation was made within each of these two groups. Thus five colony types were distinguished (1S, 1 A, 2S, 2A and 3A) as shown in Table 1. The few mutant forms which appeared during the course of the cultural studies were, with one exception, invariably of the $\mathbf{3 A}$ type and usually sterile. The sporulation of each isolate on $10 \%(\mathrm{w} / \mathrm{v})$ malt-extract solution was graded according to the magnitude of the turbidity estimate: grade $1=>0 \cdot 2$, grade $2=0 \cdot 2-0.05$ and grade $\mathbf{3}=<0 \cdot 05$. The results suggest that there is a relationship between colony type and sporulation grade as summarized in Table 2.

Groups 1 and 3 seem to be composed of extreme types: thirty-four of the fifty-one clones belonged to group 2. No group 1 clones sporulated at a 
Table 2. The relationship between sporulation grade and colony type in Venturia inaequalis

$\begin{array}{ccrcc}\begin{array}{c}\text { Colony } \\ \text { type }\end{array} & \begin{array}{c}\text { No. of } \\ \text { clones }\end{array} & \overbrace{1}^{\text {So. of clones }} & 3 \\ \text { 1S } & 2 & 2 & 0 & 0 \\ \text { 1A } & 6 & 6 & 0 & 0 \\ 2 S & 21 & 15 & 6 & 0 \\ 2 A & 13 & 2 & 7 & 4 \\ 3 A & 9 & 0 & 4 & 5\end{array}$

degree below grade 1 and no group 3 clones above grade 2 . Group 2 was fairly easily divisible into $2 \mathrm{~S}$ and $2 \mathrm{~A}$ types, high sporulation often being associated with a predominance of subaerial mycelium. Growth on the paper cylinders was similar to that on agar; group 1 clones produced a thin mycelial cover and very many conidia, and group 3 clones a very thick mycelial cover and few conidia. Conidia appeared to be evenly distributed through each culture, in contrast to Venturia pirina (see below). The relationship between profuse vegetative growth and low sporulation seems to be due, at least partly, to rapid detachment and germination of the conidia, resulting in a thickening of mycelial cover. Nevertheless, large clusters of conidia were never seen in paper cylinder cultures of group 3 clones.

A similar relationship between sporulation grade and colony type was observed during an examination of thirty-seven clones of Venturia pirina which were isolated from various varieties. The colonies were classified into the five types described under $V$. inaequalis. As noted by Herbst (1936) relatively few conidia were produced in culture and the sporulation grades were therefore adjusted as follows: grade $1=>0.02$, grade $2=0.02-0.005$ and grade $3=$ $<0.005$.

Maximal sporulation was again associated with a predominance of subaerial mycelium. The majority of clones belonged to group 2, but unlike Venturia inaequalis, a large number of $2 \mathrm{~S}$ types sporulated at the grade 2 level. High sporulation in the $2 \mathrm{~S}$ type was associated with minimal thickness of aerial mycelium and shades of dark brown or black in colony colour.

Table 3. The relationship between sporulation grade and colony type in Venturia pirina

$\begin{array}{ccccc}\begin{array}{c}\text { Colony } \\ \text { type }\end{array} & \begin{array}{c}\text { No. of } \\ \text { clones }\end{array} & \overbrace{1}^{\text {No. of clones }} & 3 \\ \text { IS } & 2 & 2 & 0 & 0 \\ \text { 1A } & 3 & 0 & 2 & 1 \\ \text { 2S } & 17 & 6 & 11 & 0 \\ \text { 2A } & 10 & 0 & 4 & 6 \\ 3 A & 5 & 0 & 1 & 4\end{array}$


Using malt-extract various attempts were made to increase the sporulation of a grade 1 clone of Venturia pirina on paper cylinders. The volume of medium was varied between 1 and $4 \mathrm{ml}$. and the extract was used at 2,5 and $10 \%(\mathrm{w} / \mathrm{v})$. Some of the paper cylinders were rotated at intervals during incubation to expose the complete surfaces for development of aerial mycelium. Significant increases in sporulation were not observed. In contrast to $V$. inaequalis, conidia are formed only on the aerial mycelium and thus the amount of mycelium available for spore production in any given culture is far less in $V$. pirina. Growth on the paper cylinders was again similar to that on agar, thin dark layers of aerial mycelium being associated with maximal sporulation and vice versa. Gentle shaking with water was efficient for removal of conidia only from the cultures; more vigorous treatment resulted in a mixture of conidia and fragments of the strongly segmented subaerial mycelium.

Measurement of sporulation as a main cultural response is obviously less satisfactory for Venturia pirina. However, in order to obtain results comparable with those from studies of $V$. inaequalis and to investigate the possibility of stimulation of sporulation, this method was adopted. Apart from categorized growth estimates, no attempt was made to explore other methods of measuring reactions to in vitro conditions.

\section{Nutritional requirements in artificial culture}

Three culture media (Table 4) were used as standards and compared with modifications which are specified below. All media except malt-extract were adjusted to $\mathrm{pH} 5 \cdot 6$ by the use of dip-type electrodes, and therefore contained traces of potassium chloride. Small amounts of malt-extract were added with

Table 4. Composition of the standard media used in studies of the nutritional requirements of Venturia inaequalis and $\mathrm{V}$. pirina

\begin{tabular}{|c|c|c|c|}
\hline \multirow[b]{2}{*}{ Constituent } & \multicolumn{3}{|c|}{ Media } \\
\hline & Dox & $\mathrm{NC}$ & $\begin{array}{c}10 \% \text { malt- } \\
\text { extract }\end{array}$ \\
\hline Glucose (g.) & $\mathbf{1} \cdot \mathbf{5}$ & $\mathbf{1} \cdot \mathbf{5}$ & - \\
\hline $\mathrm{NaNO}_{3}$ (g.) & $0 \cdot 255$ & - & - \\
\hline Casein digest (g.) & - & $0 \cdot 35$ & - \\
\hline Thiamine $(\mu \mathrm{g})$. & 一 & 30 & - \\
\hline $\mathrm{MgSO}_{4} \cdot 7 \mathrm{H}_{2} \mathrm{O}(\mathrm{g})$. & $0 \cdot 05$ & $0 \cdot 05$ & - \\
\hline $\mathrm{KH}_{2} \mathrm{PO}_{4}$ (g.) & $0 \cdot 15$ & $0 \cdot 15$ & - \\
\hline Malt-extract (g.) & - & - & $10 \cdot 0$ \\
\hline Trace element solution (ml.) & - & 100 & - \\
\hline Distilled water (ml.) & 100 & - & 100 \\
\hline
\end{tabular}

the unwashed inoculum. All the constituents were included at the concentrations given in Table 4 unless otherwise stated (nitrogen $=420 \mathrm{mg} . / 1$.). 'Dox' is the modification of Dox's Solution used by Leben \& Keitt (1948), but it was found desirable to increase the glucose concentration to $1.5 \%(\mathrm{w} / \mathrm{v})$. ' $\mathrm{NC}$ ' refers to a partially defined medium containing all the known growth requirements of Venturia species. Sodium nitrate was replaced by an enzymic digest 
of casein on a total nitrogen basis. Thiamine was included at the maximum concentration used by Leben \& Keitt, and their trace element solution was also used $(\mathrm{Zn}, 90 ; \mathrm{Cu}, 20 ; \mathrm{Mn}, 10 ; \mathrm{B}, 5 ; \mathrm{Mo}, 10 ;$ and $\mathrm{Fe}, 100 \mu \mathrm{g} . / 1$.$) . The malt-$ extract was a crystalline preparation and as the $\mathrm{pH}$ value of the solution was $5 \cdot 6$ no adjustment was necessary.

The paper cylinder cultures were incubated until they were judged to be mature, i.e. to the stage just before the beginning of spore germination which resulted in thickening of mycelial cover and the adoption of a dry and woolly appearance. As a result of rapid growth of aerial mycelium on $10 \%$ maltextract, the end-points of cultures on this medium were sometimes misjudged in the early tests (1-5) and so artificially low sporulation figures were recorded, the cultures being either too young or past the mature stage. The accompanying graphs (Figs. 1, 2) illustrate sporulation of Venturia inaequalis, clone E 1,

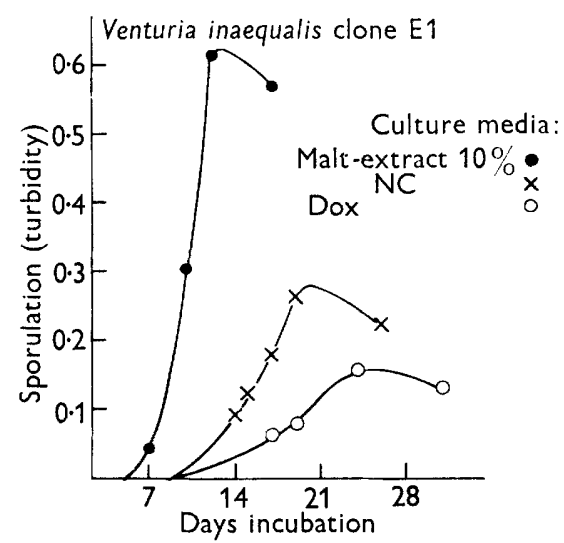

Fig. 1. Sporulation of Venturia inaequalis on three media at $18^{\circ}$.

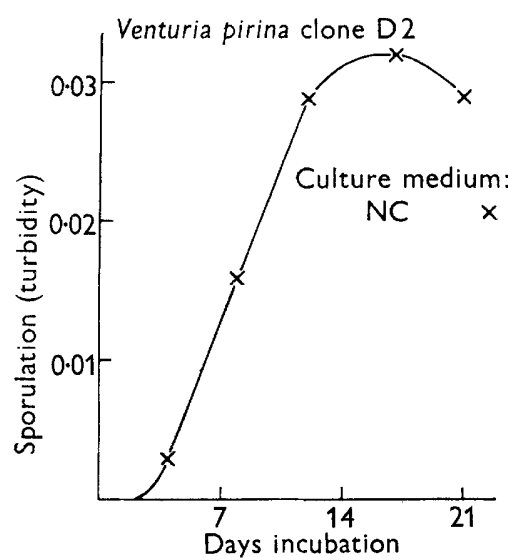

Fig. 2. Sporulation of Venturia pirina at $18^{\circ}$.

on the three standard media and of $V$. pirina, clone $\mathrm{D2}$, on medium $\mathrm{NC}$, and demonstrate the importance of taking times of maximum sporulation as cultural end-points.

Table 5 shows results obtained with Venturia inaequalis, clones $\mathbf{E} 1$ and $\mathbf{C} 1$ isolated from the varieties Edward VII and Cox's Orange Pippin respectively, and $V$. pirina clones $\mathrm{D} 2$ and $\mathrm{Cf} 5$ isolated from Durondeau and Conference respectively. Apart from the responses to urea as a nitrogen source, marked similarities were observed between the two species, and between clones of the same species which differed in other characteristics (see below). A very wide tolerance of nutritional conditions was suggested. Glucose with inorganic salts and a trace of malt-extract supported growth and sporulation, and thiamine, trace elements and casein digest appeared to be limiting factors in nutrition as found by Leben \& Keitt (1948) in their studies of $V$. inaequalis. Maximum sporulation of $V$. inaequalis occurred on $10 \%$ malt-extract, and the sporulation of this species on the defined media was best in the presence of an organic nitrogen source. These results confirm those of Rudloff (1934a) 
and Miller (1949). $V$. pirina differed from $V$. inaequalis in that maximum sporulation was not always associated with optimum growth. Rudloff (1934 $a$ ) found that growth and sporulation of $V$. inaequalis varied independently, but the present observation that cultures of this species showing optimum growth yielded most conidia, does not imply that the number of conidia per unit volume of mycelium was the same in all cultures.

Table 5. Growth and sporulation on various culture media

Venturia inaequalis, clones $\mathrm{E} 1$ and $\mathrm{C} 1 ; V$. pirina, clones $\mathrm{D} 2$ and $\mathrm{Cf} 5$

Test

no.

5

$10 \%$ malt-extract

Dox

Dox + trace elements

No. 3 + thiamine

No. 4 with $3 \times \mathrm{NaNO}_{3}$

No. 4 with $\mathrm{NaNO}_{3}$ replaced by urea

$\mathrm{NC}$

NC with sucrose, glucose and

fructose each at $0.5 \%(w / v)$

3

$10 \%$ malt-extract

Dox

Dox with sucrose, glucose and

fructose each at $0.5 \%$

No. 3 + thiamine and trace

elements

No. 4 with $\mathrm{NaNO}_{3}$ replaced by amino acids*

No. 4 with $\mathrm{NaNO}_{3}$ replaced by urea

NC with sucrose, glucose and

fructose each at $0.5 \%$

Dox

Dox with $\mathrm{NaNO}_{3}$ replaced by casein digest

\begin{tabular}{|c|c|c|c|c|c|c|c|}
\hline \multicolumn{3}{|c|}{ Sporulation } & \multicolumn{3}{|c|}{ Days incubation } & \multicolumn{2}{|c|}{$\begin{array}{l}\text { Growth } \\
\text { category }\end{array}$} \\
\hline E 1 & $\mathrm{C} 1$ & D2 & E1 C & $\mathrm{C} 1, \mathrm{D} 2$ & Cf 5 & $\mathrm{E} 1, \mathrm{C} 1$ & D2 \\
\hline $0 \cdot 229$ & $0 \cdot 269$ & 0.025 & - & 19 & - & 3 & 3 \\
\hline $0 \cdot 056$ & 0.068 & 0.016 & - & 19 & - & $\mathbf{1}$ & 1 \\
\hline $0 \cdot 060$ & $0 \cdot 085$ & 0.018 & 一 & 19 & - & 1 & 1 \\
\hline $0 \cdot 138$ & 0.072 & 0.011 & - & 19 & - & 1 & 1 \\
\hline $0 \cdot 115$ & 0.060 & $0 \cdot 004$ & - & 19 & - & 1 & 1 \\
\hline$<0.001$ & $<0.001$ & 0.034 & - & 19 & - & 0 & 2 \\
\hline $0 \cdot 389$ & $0 \cdot 275$ & 0.025 & - & 19 & - & 2 & 2 \\
\hline $0 \cdot 389$ & $0 \cdot 170$ & 0.019 & $一$ & 19 & - & 2 & 2 \\
\hline $\mathbf{E} 1$ & $\mathrm{CI}$ & Cf 5 & E 1 & C 1 & Cf 5 & E 1 & Cf 5 \\
\hline $0 \cdot 309$ & - & 0.007 & 12 & - & 18 & 3 & 3 \\
\hline $0 \cdot 186$ & - & 0.015 & 18 & 一 & 18 & 1 & 1 \\
\hline $0 \cdot 110$ & - & 0.012 & 18 & - & 18 & 1 & 1 \\
\hline $0 \cdot 269$ & - & $0 \cdot 027$ & 18 & - & 18 & 1 & 1 \\
\hline $0 \cdot 200$ & - & $0 \cdot 002$ & 12 & 一 & 18 & 2 & 1 \\
\hline 0.062 & - & $0 \cdot 032$ & 18 & 一 & 18 & 1 & 2 \\
\hline $0 \cdot 4.27$ & - & $0 \cdot 011$ & 12 & 一 & 18 & 2 & 2 \\
\hline E 1 & $\mathrm{Cl}$ & D2 & $\mathrm{E} 1, \mathrm{D} 2$ & $2 \mathrm{Cl}$ & Cf 5 & $\mathrm{E} 1, \mathrm{D} 2$ & D2 \\
\hline 0.010 & - & 0.021 & 26 & - & - & 1 & - \\
\hline 0.135 & - & 0.014 & 26 & - & - & 2 & - \\
\hline
\end{tabular}

* L-asparagine, L-glutamic acid and L-valine each at $140 \mathrm{mg} . \mathrm{N} / \mathrm{l}$.

The effects of variation of the $\mathrm{C}: \mathrm{N}$ ratio and of the concentrations of the carbon and nitrogen sources in medium NC, on the growth and sporulation of Venturia inaequalis, clones E1 and A7 (isolated from Worcester Pearmain) and $V$. pirina, clone D2, are shown in Table 6. Decrease of the casein digest concentration to one-third of the normal level is indicated as ' $\frac{1}{3} \mathrm{NC}$ ' and increase in glucose concentration as ' $\mathrm{N} 3 \mathrm{C}$ ', etc.

As expected a high degree of tolerance to variation in concentrations was observed. Decrease of sugar concentration decreased the growth and sporulation of all three clones, and decrease of nitrogen decreased sporulation. Increase of carbon and nitrogen above the normal values had little effect on $\mathbf{E} 1$ 
and decreased sporulation of A7, while clone D2 showed a distinct preference for the $\mathrm{C}: \mathrm{N}$ ratio of medium NC. Similarly, tolerance of trace elements up to twenty times the normal concentration was recorded, though this resulted in some diminution in sporulation of clones $\mathrm{E} 1, \mathrm{~A} 7$ and $V$. pirina, clone P17 isolated from Williams pear.

Table 6. Effects of variation in glucose and casein digest concentrations, in medium NC, on growth and sporulation

Venturia inaequalis, clone $\mathrm{E} 1$, incubated 19 days; $V$. inaequalis, clone A7, incubated 24 days; $V$. pirina, clone D2 incubated 18 days.

\begin{tabular}{|c|c|c|c|c|c|}
\hline \multirow{2}{*}{$\begin{array}{l}\text { Culture } \\
\text { medium }\end{array}$} & \multicolumn{3}{|c|}{ Sporulation } & \multicolumn{2}{|c|}{$\begin{array}{l}\text { Growth } \\
\text { category }\end{array}$} \\
\hline & $\mathbf{E}_{1}$ & $A 7$ & $\mathrm{D} 2$ & $\mathbf{E} 1, \mathbf{A} 7$ & D2 \\
\hline $\begin{array}{l}\frac{1}{3} \mathrm{~N} \frac{1}{3} \mathrm{C} \\
\frac{1}{3} \mathrm{NC} \\
\frac{1}{3} \mathrm{~N} \mathbf{3 C}\end{array}$ & $\begin{array}{l}0 \cdot 105 \\
0 \cdot 170 \\
0 \cdot 123\end{array}$ & $\begin{array}{l}0 \cdot 041 \\
0 \cdot 046 \\
0 \cdot 021\end{array}$ & $\begin{array}{l}0.028 \\
0.012 \\
0.007\end{array}$ & $\begin{array}{l}1 \\
2 \\
2\end{array}$ & $\begin{array}{l}1 \\
2 \\
2\end{array}$ \\
\hline $\begin{array}{l}N_{3} \mathrm{C} \\
N \\
N_{3}\end{array}$ & $\begin{array}{l}0 \cdot 155 \\
0 \cdot 263 \\
0 \cdot 251\end{array}$ & $\begin{array}{l}0 \cdot 068 \\
0 \cdot 085 \\
0 \cdot 069\end{array}$ & $\begin{array}{l}0 \cdot 020 \\
0 \cdot 044 \\
0 \cdot 009\end{array}$ & $\begin{array}{l}\mathbf{1} \\
\mathbf{2} \\
\mathbf{2}\end{array}$ & $\begin{array}{l}1 \\
\mathbf{2} \\
\mathbf{2}\end{array}$ \\
\hline $\begin{array}{l}3 \mathrm{~N} \frac{1}{3} \mathrm{C} \\
3 \mathrm{NC} \\
3 \mathrm{~N} 3 \mathrm{C}\end{array}$ & $\begin{array}{l}0 \cdot 107 \\
0 \cdot 339 \\
0 \cdot 204\end{array}$ & $\begin{array}{l}0 \cdot 043 \\
0 \cdot 060 \\
0 \cdot 018\end{array}$ & $\begin{array}{l}0.017 \\
0.026 \\
0.042\end{array}$ & $\begin{array}{l}1 \\
2 \\
2\end{array}$ & $\begin{array}{l}1 \\
2 \\
3\end{array}$ \\
\hline
\end{tabular}

\section{Pathogenicity and host range}

The host range of a clone is defined as the degrees of pathogenicity observed on a series of host varieties graded according to disease resistance under field conditions. Miller's Seedling and Conference were included as resistant apple and pear varieties respectively, and Cox and Williams as less resistant, other varieties being initially classed as intermediates. Four replicate trials were planned, using six clones each of Venturia inaequalis and V. pirina, and were carried out as far as limitations of space and material permitted. In addition to the clones mentioned above, $V$. inaequalis clone A 20, isolated from Laxton's Superb, A6 from Worcester Pearmain and A26 from Cox's Orange Pippin were tested, and also V. pirina, P6 from Laxton's Superb, P16 from Williams' Bon Chrétien and Cf3 and 81' from Conference. Owing to the use of surplus nursery material it was not possible to obtain all the apple varieties on Malling II. Some varieties were included on more than one rootstock to demonstrate any possible effects on resistance. In each experiment symptoms of infection were recorded 30 and 50 days after inoculation, using the following disease categories : $0=$ no reaction; $1=$ fleck; $2=$ lesion; $3=$ high incidence of disease with defoliation.

The result of the four trials in terms of the maximum category number observed in each combination of clone and variety are summarized in Table 7. Clone E1, originally isolated from Edward VII which is a comparatively resistant variety, had the widest host range on the graded series of apple varieties, while clones $\mathbf{C} 1$ and A 26 produced lesions only on Cox and Newton. No symptoms of infection were observed on the highly resistant variety 
Miller's Seedling and no distinct rootstock effects were recorded. In contrast to the reactions of clone $\mathrm{E} 1$ on the apple varieties, clones $\mathrm{Cf} 3$ and $81^{\prime}$ from Conference pear, which was classified as a resistant variety in 1951, were least pathogenic on the pear varieties. All the clones of Venturia pirina were pathogenic on Conference, though disease incidence was generally light and symptoms were not visible by the thirty-day record. There was some indication that Williams pear was more susceptible on Quince A than on Quince C.

Table 7. Host ranges of six clones each of Venturia inaequalis and V. pirina. Maximum disease category number observed in each combination of clone and variety

Varieties arranged in increasing order of resistance.

Clone of pathogen and variety of origin

\begin{tabular}{l}
$\quad$ Apple variety \\
Cox's Orange Pippin \\
Cox's Orange Pippin \\
Newton Wonder \\
Worcester Pearmain \\
Worcester Pearmain \\
James Grieve \\
Laxton's Superb \\
Edward VII \\
Miller's Seedling \\
$\quad$ Pear variety \\
\multicolumn{1}{c}{$\quad$} \\
Williams' Bon Chrétien \\
Williams' Bon Chrétien \\
Doyenné du Comice \\
Laxton's Superb \\
Beurré d'Amanlis \\
Beurré Hardy \\
Beurré Hardy \\
Conference
\end{tabular}

Rootstock
Malling II
Malling IV
Malling XVI
Malling II
Malling IV
Malling VII
Malling II
Malling VII
Malling IV


Rootstock
Quince A
Quince C
Quince A
Quince A
Quince A
Quince A
Quince C
Quince A

$\begin{array}{cc}\text { E1 } 1 & \text { La } \\ \text { Edward } & \text { S } \\ 3 & \\ 3 \\ 2 \\ 2 \\ 3 \\ 2 \\ 2 \\ 2 \\ 0\end{array}$

A 20

axton's

$\begin{array}{cc}\text { P6 } & \mathrm{D2}^{2} \\ \text { Laxton's } & \text { Duron- }\end{array}$

Superb deau

$\begin{array}{ll}2 & 2 \\ 1 & 2 \\ 2 & 2 \\ 2 & 1 \\ 2 & 0 \\ 2 & 2 \\ 2 & 2 \\ 2 & 2\end{array}$

A7
Worcester
3
3
3
3
2
2
2
1
0
0

$\underset{\text { Williams }}{\text { P16 }}$

3

\section{2}

2

2

2

$$
1
$$$$
1
$$

A6
Worcester
2
2
2
2
2
1
1
0
0

P17
Williams
2
2
2
0
2
1
1
2

$\begin{array}{cc}\text { A 26 } & \text { C1 } \\ \text { Cox } & \text { Cox } \\ 3 & 2 \\ 3 & 3 \\ 2 & 3 \\ 0 & 1 \\ 1 & 0 \\ 1 & 1 \\ 1 & 1 \\ 0 & 0 \\ 0 & 0 \\ \text { Cf3 } & 81^{\prime} \\ \text { Con- } & \text { Con- } \\ \text { ference } & \text { ference } \\ 2 & 2 \\ 1 & 1 \\ 2 & 2 \\ 1 & 1 \\ 0 & 0 \\ 1 & 1 \\ 1 & 1 \\ 2 & 2\end{array}$

Stability in culture and the effects of re-isolation from artificial infection

Stability in culture is defined as the maintenance of unchanged sporulation grade, colony type and pathogenicity during storage at $5^{\circ}$ on $2 \%$ maltextract agar under paraffin oil. Six clones each of Venturia inaequalis and $V$. pirina were periodically re-isolated from inoculated shoots of Cox's Orange Pippin and Williams' Bon Chrétien respectively. In no case was any clone except the one used as inoculum recovered from a given tree, which showed that no spread of infection was occurring under the greenhouse conditions. The behaviour of the clones during storage periods of five years (E1, C1, D2 and Cf3) and four years (A6, A7, A20, A26, P6, P16, P17 and 81') is shown in Table 8. At the time of the first re-isolation, clones E1, C1, D 2 and Cf 3 had been stored for two years while the remainder had been isolated only one year previously. The time intervals between the four re-isolations were 1-2, eleven 


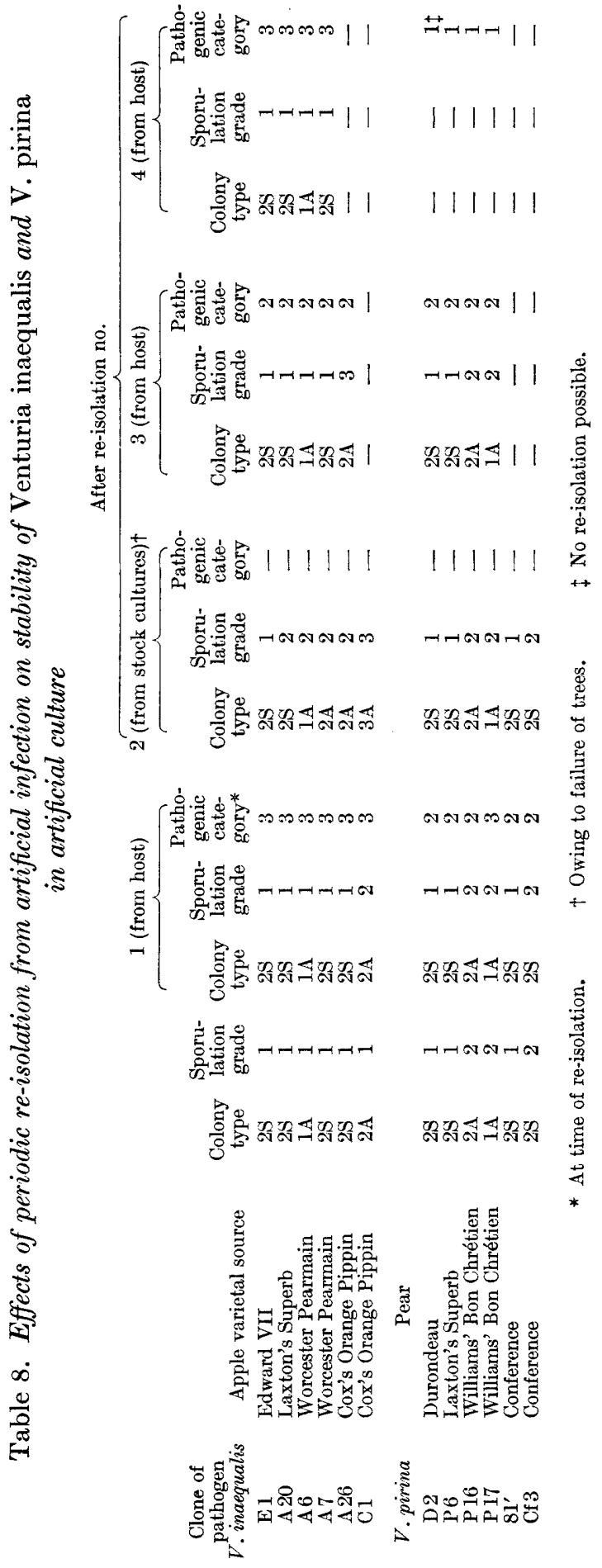


months; 2-3, seven months; $3-4$, fourteen months. All the clones were isolated as single conidia from the stock cultures at the second re-isolation, owing to a failure of trees in the greenhouse. Consequently eighteen months elapsed between re-isolations 1 and 3 from artificial infection.

Venturia inaequalis showed a tendency to increased development of aerial mycelium associated with reduced sporulation and loss of pathogenicity on Cox. Clones E 1 and A20, which had the widest host ranges, were the most stable, and C1 and A26 the least stable. All except the least stable clones regained their wild-type characteristics after re-isolation from Cox, and it is thought that the unstable types, $\mathrm{Cl}$ and A26, might have been retained in culture with frequent re-isolation. In contrast, no evidence was obtained of changes in cultural characters of $V$. pirina, but pathogenicity declined rapidly under the storage conditions. At the third re-isolation only a few scattered lesions were observed, and fourteen months later no sporulating lesions were produced and recovery of the clones was not possible. At the time of the host range trials (Table $\boldsymbol{\gamma}$ ) the clones of $V$. pirina had been stored in culture for either one (P6, P16, P17 and $\left.81^{\prime}\right)$ or two years (D2 and Cf 3$)$ and the results of these would therefore seem to indicate rather the maintenance of pathogenicity during the storage period than the actual host ranges of the wild-types.

\section{DISCUSSION}

The clones of Venturia inaequalis showed relationships between degree of resistance of host source, host range, and stability in culture. There was some indication that deviation from the wild type, observed as change in colony type or sporulation grade, indicated decreased pathogenicity on Cox, and the most stable clones had the widest host ranges on the varieties tested. No such relationships were observed in the study of $V$. pirina; in all cases cultural characters remained unchanged during prolonged storage, but pathogenicity declined. Nevertheless, variations in the maintenance of pathogenic capabilities on Williams were observed; thus $V$. pirina clone $\mathrm{D} 2$ was midly pathogenic eighteen months after re-isolation, while another clone (not referred to in the text), isolated from Williams was non-pathogenic eleven months after isolation. There was also some indication of specialization of the Conference clones on Conference, as found by Stanton $(1953 b)$. Thus, in this instance, clones isolated from a variety which was regarded as resistant in 1951, had the narrowest host range.

Previous workers have not found these differences between Venturia inaequalis and $V$. pirina, though few have carried out parallel experiments on the two species. Herbst (1936), Langford \& Keitt (1942) and Stanton (1953 $a, b)$ found their isolates of $V$. pirina to be culturally stable, apart from the occasional production of sectors. The English and American workers also found no relationship between host source and host range in V. pirina. Similarly, Küthe (1935), Rudloff (1934a), and Keitt \& Langford (1941) stated that their isolates of $V$. inaequalis showed unchanged colony characters and pathogenic capabilities after prolonged storage on natural media, though they did not use the 
paraffin oil method. Palmiter (1934) and Schmidt (1936b) also found no relationship between host source and host range in this species.

A larger number of clones would have to be examined before the relationships outlined above could be definitely established, and before differences between the species, in respect of these relationships, could be fully evaluated. There appear to be several factors of importance in this apparent discrepancy with the results of previous workers. The six clones of each species, which were selected for detailed study, had been collected from series of commercially important varieties varying as widely as possible in their degree of resistance to scab. This variation occurs to a considerably greater extent among apple varieties than among pear varieties commonly grown in England. Therefore, the wider divergence in the clonal characteristics of Venturia inaequalis is, perhaps, not unexpected. Clone E 1, from the resistant variety Edward VII, was obtained only after prolonged search, while isolates were easily obtained from Conference, which was classified as a resistant variety when the isolations were made. It must however, be remembered that clone $\mathbf{E} \mathbf{1}$ has a wide host range and therefore might have been isolated from Cox, in which case the relationships described above would not have been apparent. Furthermore, as varietal resistance varies with locality, it could not be stated that, for example, isolates from Edward VII would invariably show characteristics similar to clone E1. It is suggested that the percentage of E1-type isolates obtained from an apple variety which is highly resistant in a given locality, may be greater than the percentage obtained from less resistant varieties in the same locality.

In both species of Venturia a relationship was established between colony type, which is genetically determined in the ascus, and sporulation on an optimum medium. The results confirm those of Rudloff (1934 $b$ ) and Herbst (1936) and also show that maximum sporulation appears to be associated with minimal development of aerial mycelium. There were no relationships within the species either between cultural characters and stability in culture or, in accordance with the results of the German and American workers, between cultural characters and host range or host variety. Thus, the choice of grade 1 clones, which are best suited to studies of sporulation, has not prejudiced the inclusion of widely differing types among those selected for detailed study. It is suggested that, in the choice of clones of $V$. inaequalis as routine sources for large numbers of conidia over long periods, due account should be taken of the characters and relationships outlined above. Yearly re-isolation from artificial infection may be necessary to maintain the wild clonal type, as monoconidial transfer from the stock cultures in no case induced a return to normal. Clone $\mathbf{E} 1$ of $\boldsymbol{V}$. inaequalis has been successfully used in these laboratories for spore germination tests of protective fungicides during the period 1949-56 and is unchanged in all observed characteristics. The use of $V$. pirina as a routine source of conidia presents a more difficult problem because of the low degrees of sporulation observed in culture. Choice of clone must be based on sporulation grade and frequent re-isolation seems to be necessary for the maintenance of the wild pathogenic type. 
Apart from response to urea, no major differences in nutritional requirement were observed either between the species or between clones that differed widely in other characteristics. Even though differences have been found by Rudloff (1934a), Leben \& Keitt (1948), Pelletier \& Keitt (1954) and Fothergill \& Ashcroft (1955) no attempt has been made to assess the importance of variation in the metabolism of varieties, characterized by different degrees of resistance, in the host relations of the pathogens.

The author wishes to thank Dr R. V. Harris for his advice and interest during the course of the work, Miss Jean Richardson for technical assistance and Mr G. M. Jolly for advice on the statistical treatment of results.

\section{REFERENCES}

Bueli, C. B. \& Weston, W. H. (1947). Application of the mineral oil conservation method to maintaining collections of fungus cultures. Amer. J. Bot. 34, 555 .

Fothergill, P. G. \& Ashcroft, R. (1955). The nutritional requirements of Venturia inaequalis. J. gen. Microbiol. 12, 387.

Hersst, W. (1936). Venturia pirina Aderhold. 1. Zur Formenmannigfaltigkeit des Pilzes. Gartenbautiss. 10, 428.

Keitt, G. W. \& Langford, M. H. (1941). Venturia inaequalis (Cke.) Wint. 1. A groundwork for genetic studies. Amer. J. Bot. 28, 805.

KIrby, A. H. M. \& Frick, E. L. (1952). Modifications in the glass-slide sporegermination test for use in fungicide research. Rep. E. Malling Res. Sta. p. 161.

KIrKhaM, D. S. (1956). A culture technique for Venturia spp. and a turbidimetric method for the estimation of comparative sporulation. Nature, Lond. 178, 550.

Küтнe, K. (1935). Zur Infektion und Kultur des Apfelschorfes, Venturia inaequalis (Cooke) Aderhold. Gartenbauziss. 9, 405.

LANGFord, M. H. \& KeITT, G. W. (1942). Heterothallism and variability in Venturia pirina. Phytopathology, 32, 357.

Leben, C. \& KeITt, G. W. (1948). Venturia inaequalis (Cke.) Wint. V. The influence of carbon and nitrogen sources and vitamins on growth in vitro. Amer. J. Bot. 35,337 .

Mrller, H. J. (1949). Modifications on the slide-germination method of evaluating fungicides including the use of Venturia inaequalis and Phytopthora infestans. Phytopathology, 39, 245.

Montgomery, H. B. S. \& Moore, M. H. (1938). A laboratory method for testing the toxicity of protective fungicides. J. Pomol. 15, 253.

Palmiter, D. H. (1934). Variability in monoconidial cultures of Venturia inaequalis. Phytopathology, 24, 22.

Pelletier, R. L. \& Keitt, G. W. (1954). Venturia inaequalis (Cke.) Wint. VI. Amino acids as sources of nitrogen. Amer. J. Bot. 41, 362.

Rublofy, C. F. (1934a). Venturia inaequalis (Cooke) Aderhold. 1. Der Einfluss des Nährbodens auf den Pilz und die Erhaltung seiner Pathogenität. Gartenbauwiss, $9,65$.

RUdloff, C. F. (1934b). Venturia inaequalis (Cooke) Aderhold. III. Zur Formenmannigfaltigkeit des Pilzes. Gartenbaurwiss. 9, 105.

Rudloff, C. F. \& Schmidt, M. (1934). Venturia inaequalis (Cooke) Aderh. II. Zur Züchtung schorfwiderstandsfähiger Apfelsorten. Zïchter, 6, 288.

Schmidt, M. (1935). Venturia inaequalis (Cooke) Aderhold. IV. Weitere Beiträge zur Rassenfrage beim Erreger des Apfelschorfes. Gartenbauziss. 9, 364.

Schмidт, M. (1936a). Venturia inaequalis (Cooke) Aderhold. V. Weitere Untersuchungen über die auf verschiedenen Bäumen lebenden Populationen des Apfelschorfpilzes. Gartenbauwiss. 10, 422. 
Schмid, M. (1936b). Venturia inaequalis (Cooke) Aderhold. VI. Zur Frage nach dem Vorkommen physiologisch spezialisierter Rassen beim Erreger des Apfelschorfes. Erste Mitteilung. Gartenbaurwiss. 10, 478.

Stanton, W. R. (1951). The use of thin polythene sleeving for moist chambers in inoculation studies. Phytopathology, 41, 476.

Stanton, W. R. (1953a). Field variation in Venturia pirina. Trans. Brit. mycol. Soc. $36,90$.

Stanton, W. R. (1953b). Breeding pears for resistance to the pear scab fungus Venturia pirina Aderh. I. Variation in the pathogenicity of Venturia pirina. Ann. appl. Biol. 40, 184.

(Received 13 September 1956) 